\title{
Ebstein's anomaly: sixteen years' experience with valve replacement without plication of the right ventricle
}

\author{
P RAJ BEHL, A BLESOVSKY \\ From the Department of Cardiothoracic Surgery, Regional Cardiothoracic Centre, Freeman Hospital, \\ Newcastle upon Tyne
}

ABSTRACT From June 1967 to February 198310 patients aged from 13 to 51 years underwent surgery for Ebstein's anomaly. Nine patients were in class III according to the New York Heart Association (NYHA) classification and one was in class IV. The interatrial communication was closed in all patients; the tricuspid valve was repaired in one patient and replaced in the other nine patients. There were no deaths in hospital but there were two late deaths. One patient died when the tricuspid prosthesis clotted seven years after its insertion. The other patient committed suicide 11 years after surgery. The remaining eight patients have been followed up for periods ranging from six months to 16 years (mean 10 years). Seven of the eight survivors are well and in NYHA class I, the eighth being in class II. Cardiac arrhythmias have been a problem in only one patient. Tricuspid valve replacement combined with closure of interatrial communication without right ventricular plication has given satisfactory clinical results and has improved the quality of life.

The curious malformation of the tricuspid valve described by Ebstein ${ }^{1}$ is a rare congenital cardiac abnormality, the cardinal features being the downward displacement of the tricuspid valve and the right ventricular dilatation. Many variations, however, in structure and position of leaflets, chordae, and papillary muscles and in the internal morphology of the right ventricle as well as other cardiac anomalies have been described. ${ }^{23}$ Despite the early encouraging reports ${ }^{4-6}$ controversy still surrounds the role of valve replacement in the management of Ebstein's anomaly. There are few reports ${ }^{7-13}$ which describe the long term follow up of patients after surgical intervention in this disease. Consequently there is considerable divergence of opinion with much uncertainty about the ideal surgical approach and optimal management of the condition. The purpose of our study was to review our 16 year experience of tricuspid valve replacement combined with closure of the interatrial communication without plication of the atrialised portion of the right ventricle,

Address for reprint requests: Mr A Blesovsky, Freeman Hospital, Freeman Road, Newcastle upon Tyne NE7 7DN .

Accepted 10 October 1983 in the belief that this would be helpful for managing patients with Ebstein's malformation in the future.

\section{Patients and methods}

From June 1967 to February 198310 patients (five male and five female) with Ebstein's anomaly were managed surgically in our unit (table 1 ), their ages ranging from 13 to 51 years. The commonest symptom (in $90 \%$ ) was dyspnoea of varying degrees; seven patients $(70 \%)$ showed cyanosis, and the other symptoms were fatigue, palpitations, vertigo, and syncope. The patients were evaluated according to the New York Heart Association (NYHA) classification: nine were in class III and one was in class IV. Electrocardiography showed normal sinus rhythm in nine patients and atrial fibrillation in one. The axis was between +90 and +120 in six, +60 in one, zero in two, and -60 in one. Complete right bundle branch block was observed in nine patients and incomplete right bundle branch block in one. Two patients had first degree atrioventricular block and an accessory conduction pathway was found in one. All patients were subjected to cardiac catheterisation, which confirmed the diagnosis of the $\mathrm{Eb}$ - 
Table 1 Clinical presentation of the 10 patients

\begin{tabular}{|c|c|c|c|c|c|}
\hline $\begin{array}{l}\text { Patient } \\
\text { No }\end{array}$ & $\begin{array}{l}\text { Age } \\
(y)\end{array}$ & Sex & Symptoms & $E C G$ & $\begin{array}{l}\text { Functional } \\
\text { class* }\end{array}$ \\
\hline 1 & 40 & $\mathbf{M}$ & Cyanosis, dyspnoea, palpitations & SR, RBBB, axis $+60,1$ st degree & III \\
\hline 2 & 17 & $\mathbf{F}$ & $\begin{array}{l}\text { Cyanosis, dyspnoea, hypoxia, } \\
\text { syncope, congestive heart failure }\end{array}$ & SR, RBBB, axis + 120 & IV \\
\hline 3 & 13 & $\mathbf{M}$ & Cyanosis, dyspnoea, palpitations & $\begin{array}{l}\text { SR, RBBB, axis }+120,1 \text { st } \\
\text { degree AV block }\end{array}$ & III \\
\hline $\begin{array}{l}4 \\
5 \\
6 \\
7\end{array}$ & $\begin{array}{l}30 \\
34 \\
31 \\
45\end{array}$ & $\begin{array}{l}\mathbf{F} \\
\mathbf{M} \\
\mathbf{F} \\
\mathbf{F}\end{array}$ & $\begin{array}{l}\text { Cyanosis, dyspnoea, fatigue } \\
\text { Dyspnoea, palpitations, vertigo } \\
\text { Cyanosis, fatigue, syncope } \\
\text { Cyanosis, dyspnoea, fatigue, } \\
\text { palpitations }\end{array}$ & $\begin{array}{l}\text { SR, RBBB, axis }+120 \\
\text { SR, RBBB, axis }-60 \\
\text { SR, RBBB, axis }+90 \\
\text { SR, incomplete RBBB, axis } 0\end{array}$ & $\begin{array}{l}\text { III } \\
\text { III } \\
\text { III } \\
\text { III }\end{array}$ \\
\hline $\begin{array}{r}8 \\
9 \\
10\end{array}$ & $\begin{array}{l}37 \\
51 \\
17\end{array}$ & $\begin{array}{l}\mathbf{F} \\
\mathbf{M} \\
\mathbf{M}\end{array}$ & $\begin{array}{l}\text { Cyanosis, dyspnoea, palpitations } \\
\text { Dyspnoea, palpitations } \\
\text { Dyspnoea, fatigue }\end{array}$ & $\begin{array}{l}\text { SR, axis 0 } \\
\text { AF, RBBB, axis }+120 \\
\text { SR, RBBB, axis }+120\end{array}$ & $\begin{array}{l}\text { III } \\
\text { III } \\
\text { III }\end{array}$ \\
\hline
\end{tabular}

${ }^{*}$ New York Heart Association criteria. SR-sinus rhythm; BBB-bundle branch block; AV-atrioventricular; AF-atrial fibrillation.

stein's anomaly. Echocardiography was used only in the last patient. Nine patients had moderate cardiac enlargement with a cardiothoracic ratio (CTR) varying from $54 \%$ to $67 \%$; in one patient the CTR was $50 \%$. All patients had an associated atrial septal defect; four had the secundum type and six a persistent foramen ovale.

Routine cardiopulmonary bypass was initiated, after median sternotomy, with an aortic and two caval cannulas. Left ventricular apical venting was used for preventing cardiac distension and for removing intracardiac air at the end of the procedure. Normothermic perfusion was used in all patients and the surgical procedure was carried out with the hearts beating.

The interatrial communication was closed in all patients. The first patient had a plastic procedure with repositioning of the posterior leaflet at the annular level, while the remaining nine patients had a tricuspid prosthesis implanted. In four patients the prosthesis was inserted without excision of the native tricuspid valve. In eight out of the nine patients who had tricuspid valve replacement the posterior half of the prosthesis was placed above the level of the coronary sinus and at annular level in the ninth, where a fringe of tissue was present. A Hammersmith prosthesis was used in one patient and Beall valves in five other patients. In the last three patients the tricuspid valve was replaced by a Carpentier Edwards bioprosthesis.

The last patient in the series had evidence of an aberrant conduction pathway causing recurrent tachycardia. This bundle was identified by electrophysiological mapping at operation and was interrupted successfully by the sutures used to attach the tricuspid prosthesis.

\section{Results}

\section{EARLY OUTCOME}

There was no hospital mortality and none of the patients suffered from surgically induced heart block. Three patients developed atrial fibrillation and were successfully cardioverted; one of these (patient 9) and two others showed a slight increase in cardiothoracic ratio in the immediate postoperative period.

\section{LATE OUTCOME}

Mortality There were two late deaths. The patient who had had the tricuspid valvuloplasty committed suicide after 11 years and the second patient died after seven years when the Beall valve clotted.

Valve complications None of the five patients who had Beall valve implantation was given anticoagulants. Three of these five have had no complication in 15 years since operation; one patient, as already noted, died from a thrombosed Beall prosthesis after seven years, and the fifth had a thrombosed Beall valve replaced, three months after its insertion, by a Björk-Shiley valve. This in turn thrombosed in two years despite anticoagulant treatment; it was therefore replaced by a mounted aortic homograft, which has worked successfully for nearly 10 years. The patient with a Hammersmith prosthesis (case 2) developed a raised jugular venous pressure during pregnancy. This returned to normal after delivery. There have been no complications with the heterograft valves.

Heart size There was no dramatic decrease in cardiac size in any patient. In nine patients it became smaller gradually and in one it remained unchanged (fig).

Effort tolerance The patient who had tricuspid valvuloplasty had overall a less satisfactory result. His tricuspid valve remained incompetent, but his symptoms improved because the frequency of paroxysmal tachycardias decreased, their duration shortened and 


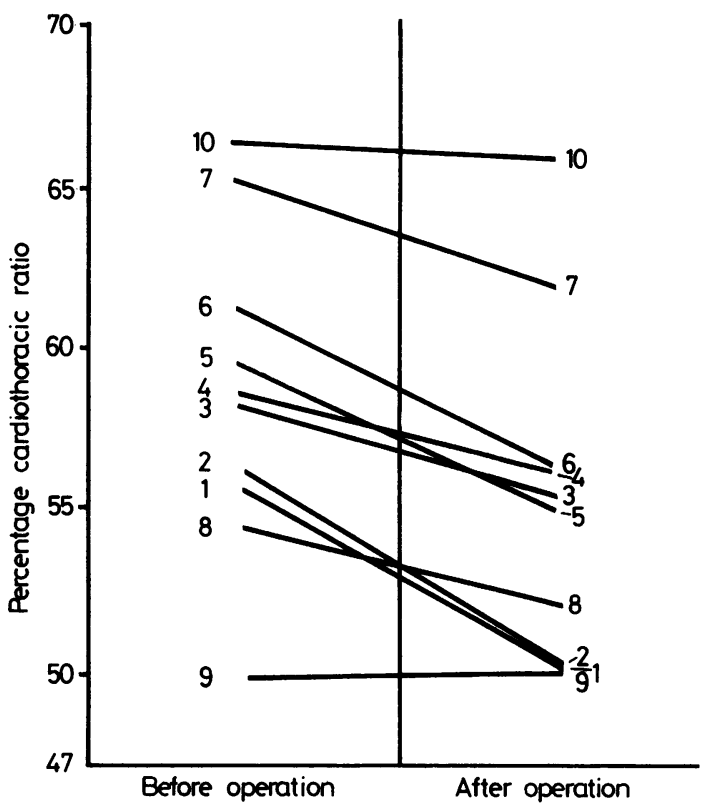

Change in heart size in the patients (Nos 1-10) as determined by preoperative and postoperative cardiothoracic ratios.

they no longer precipitated heart failure. He was in functional class II (NYHA) before committing suicide. Out of eight survivors six are in class $I$, one in class II and one had operation too recently to assess the final results, though at six months he is much improved.

Late arrhythmias Late arrhythmias were observed in four patients. The patient in whom the prosthesis was sutured inferior to the coronary sinus (case 7) suffered from arrhythmias quite out of proportion to those of other patients. She was cardioverted soon after the operation and then continued to have attacks of ventricular tachycardia. Three years after the operation she was admitted to hospital on two occasions with paroxysmal supraventricular tachycardia. DC shocks converted her back to sinus rhythm. Since then she has remained in functional class I and underwent successful cholecystectomy eight years after her first cardiac operation. In another patient (No 1) arrhythmic episodes lasted for four years, diminishing in their frequency and duration. Of the remaining two patients, one (No 5) had transient episodes of ventricular tachycardia at six and eight years after the operation and the other (No 9) manifested atrial fibrillation at two years. He was cardioverted to atrial flutter with $4: 1$ block and has been stable in that rhythm for two years. All these patients have tolerated their arrhythmias well without significant haemodynamic disturbances.

Pregnancy One patient (No 6) had two full term normal deliveries. She had her tricuspid valve replaced by a Beall prosthesis and was not given anticoagulants. The patient with the Hammersmith valve (No 2) was given anticoagulants and had two early abortions. The third pregnancy was managed by replacing warfarin with subcutaneous heparin and it ended successfully with the birth of a healthy child at full term.

Follow up Of the eight survivors, one has been followed for 16 years, three for 15 years, and one for 12 years. The remaining three continue to do well from six months to six years after surgery. The results have been summarised in table 2 .

\section{Discussion}

The natural history of Ebstein's disease is variable and fascinating. Though less than $5 \%$ of patients live beyond the age of $50,{ }^{2} 60 \%$ of those who survive infancy and attain adulthood live comfortably in NYHA class I or II. ${ }^{14}$ Some patients even progress to the eighth ${ }^{215}$ and, rarely, to the ninth decade. ${ }^{16}$

Two fundamental questions therefore arise: (1) At what time in the natural history of the disease should surgical intervention be considered? (2) What type of surgical procedure should be undertaken? We concur with others ${ }^{78}$ that medical treatment should be abandoned in favour of surgery when patients deteriorate to class III or IV or when symptoms such as severe cyanosis, embolic episodes, progressive increase in cardiac size, and symptomatic arrhythmias supervene over class II disability.

Although superior vena caval to pulmonary artery anastomosis ${ }^{17}$ and a modified Fontan operation ${ }^{18}$ for the imperforate form of Ebstein's anomaly have been performed, the two main surgical techniques for its management have been tricuspid valve replacement with or without ventricular plication ${ }^{479-1319}$ and various types of plastic repair, ${ }^{820-22}$ with dissimilar operative and long term results. Plastic repair will be suitable in patients having mild to moderate degrees of downward displacement of the tricuspid valve with adequate leaflets and a relatively good sized functioning right ventricle. In our patients the pathological anatomy of the tricuspid valve has not favoured reconstructive procedures, with the exception of our first patient. The tricuspid valves were grossly deranged with fusion of papillary muscles, non-recognisable chordae tendinae, or bizarre attachments of the anterior and posterior leaflets and with a diminutive or rudimentary septal leaflet. All the valves were incompetent. Any attempt at recon- 
Table 2 Surgical treatment and the postoperative results

\begin{tabular}{|c|c|c|c|c|c|c|}
\hline \multirow{2}{*}{$\begin{array}{l}\text { Patient } \\
\text { No }\end{array}$} & \multirow{2}{*}{$\begin{array}{l}\text { Year of } \\
\text { operation }\end{array}$} & \multirow{2}{*}{$\begin{array}{l}\text { Valve } \\
\text { used }\end{array}$} & \multicolumn{2}{|c|}{ Postoperative course } & \multirow{2}{*}{$\begin{array}{l}\text { Functional } \\
\text { class }^{*}\end{array}$} & \multirow{2}{*}{$\begin{array}{l}\text { Total } \\
\text { follow up } \\
(y)\end{array}$} \\
\hline & & & Early & Late & & \\
\hline 1 & 1967 & Valvuloplasty & AF, cardioverted & Arrythmic episodes for $4 y$ & II & 11 (committed suicide) \\
\hline 2 & 1967 & Hammersmith & $\begin{array}{l}\text { To SR } \\
\text { Uneventful }\end{array}$ & $\begin{array}{l}\text { Two abortions, one normal } \\
\text { delivery }\end{array}$ & $\mathbf{I}$ & 16 \\
\hline $\begin{array}{l}3 \\
4 \\
5\end{array}$ & $\begin{array}{l}1968 \\
1968 \\
1968\end{array}$ & $\begin{array}{l}\text { Beall } \\
\text { Beall } \\
\text { Beall }\end{array}$ & $\begin{array}{l}\text { Uneventful } \\
\text { Uneventful } \\
\text { Uneventful }\end{array}$ & $\begin{array}{l}\text { Uneventful } \\
\text { Valve clotted at } 7 \mathrm{y} \\
\text { Ventricular tachycardia at } 6 \\
\text { and } 8 \mathrm{y}\end{array}$ & $\begin{array}{l}\text { I } \\
\text { I } \\
\text { II }\end{array}$ & $\begin{array}{l}15 \\
7 \text { (died) } \\
15\end{array}$ \\
\hline 6 & 1968 & Beall & $\begin{array}{l}\text { AF, cardioverted } \\
\text { to } \mathrm{SR}\end{array}$ & Normal deliveries at 2 and $4 y$ & I & 15 \\
\hline 7 & $\begin{array}{l}1971 \\
1971 \\
1973\end{array}$ & $\begin{array}{l}\text { Beall } \\
\text { Björk } \\
\text { Aortic homograft }\end{array}$ & $\begin{array}{l}\text { Uneventful } \\
\text { Uneventful } \\
\text { SVT, DC shock, } \\
\text { SR }\end{array}$ & $\begin{array}{l}\text { Valve clotted at } 3 \mathrm{~m} \\
\text { Valve clotted at } 2 \mathrm{y} \\
\text { VEs and tachycardiac episodes } \\
\text { up to } 3 \mathrm{y} \text {; required DC shock } \\
\text { twice. Cholecystectomy at } \\
8 \mathrm{y}\end{array}$ & $\mathbf{I}$ & 12 \\
\hline 8 & 1977 & $\begin{array}{l}\text { Carpentier- } \\
\text { Edwards }\end{array}$ & Uneventful & Repair epigastric hernia at $4 y$ & I & 6 \\
\hline 9 & 1978 & $\begin{array}{l}\text { Carpentier- } \\
\text { Edwards }\end{array}$ & $\begin{array}{l}\text { AF, cardioverted } \\
\text { to } \mathrm{SR}\end{array}$ & $\begin{array}{l}\text { AF at } 2 \mathrm{y} \text {; cardioverted to } \\
\text { atrial flutter with } 4: 1 \text { block }\end{array}$ & I & 3 \\
\hline 10 & 1983 & $\begin{array}{c}\text { Carpentier- } \\
\text { Edwards }\end{array}$ & Uneventful & Uneventful & $\begin{array}{l}\text { Not } \\
\text { assessed }\end{array}$ & $1 / 2$ \\
\hline
\end{tabular}

*New York Heart Association criteria.

AF-atrial fibrillation; SR-sinus rhythm; SVT-supraventricular tachycardia; VEs_ventricular ectopics.

struction would have left a regurgitant tricuspid valve, which happened in our first patient and prompted a change in our attitude towards plastic reconstruction.

The cause of haemodynamic disturbance in Ebstein's anomaly, according to Sealy, ${ }^{23}$ is the obstruction between the atrialised right ventricle and the functioning right ventricle or a small functioning right ventricle. Excision of the deformed tricuspid valve with its replacement by a competent prosthesis not only removes the obstructive element between the atrialised ventricle and the functioning right ventricle but also prevents tricuspid regurgitation, thereby benefiting the size and function of the right ventricle. Danielson and Fuster, ${ }^{8}$ who have reported satisfactory clinical results with plastic repair (based on construction of a monocusp valve of anterior tricuspid leaflet combined with plication, posterior tricuspid annuloplasty, and right atrial reduction), agree that not all patients are suitable for the procedure. Moreover, we are not aware of substantially convincing data that would support the long term results of plastic procedures over valve replacement. Consequently, we have persisted with tricuspid valve replacement, with satisfactory clinical results. Debate continues about the surgical management of the atrialised portion of the right ventricle, which is thin walled but has normal myocardial cells with ventricular innervation. ${ }^{5}$ Viewed externally this part is small and thin walled; viewed from inside the heart the major part of the atrialised ventricle is formed by thickened ventricular septum. In all our patients the thin walled part contracted synchron- ously with the ejecting ventricle. We did not make any attempt therefore to plicate the atrialised portion of the right ventricle because of these observations. It was, however, part of the plastic reconstruction of the tricuspid valve performed in the first patient. Excellent clinical results have been achieved by replacing the tricuspid valve without right ventricular plication, ${ }^{1924}$ with clear angiographic demonstration of continuous global contraction of the right ventricle after operation. ${ }^{24}$ Table 3 shows the long term results achieved by various authors after tricuspid valve replacement with or without plication of the atrialised right ventricle.

Lillehei and associates ${ }^{5}$ argued against the immediate closure of the interatrial defect because of the possibility of postoperative congestive heart failure. Our experience and that of others, ${ }^{1012}$ however, does not bear this out. We closed the interatrial communication in all our patients. Our belief is that heart failure occurs rarely, if at all, after a competent tricuspid valve mechanism has been achieved by valve replacement. On the other hand if the defect is not repaired or is partially closed the interatrial channel remains open, with the possibility that cyanosis will result from right to left shunt and the risk of paradoxical emboli. Barbero-Marcial and colleagues $^{7}$ lost one patient in whom the atrial septal defect had been partially closed, possibly because of an embolic brain abscess. This incident led them to change their policy and in the latter part of their series they closed the defect in all patients.

The question of what type of prosthetic valve should be used for tricuspid valve replacement 
Table 3 Results of tricuspid valve replacement with or without plication of right ventricle

\begin{tabular}{|c|c|c|c|c|c|c|c|c|}
\hline \multirow{2}{*}{$\begin{array}{l}\text { Authors and } \\
\text { year of } \\
\text { publication }\end{array}$} & \multirow{2}{*}{$\begin{array}{l}\text { No of } \\
\text { patients }\end{array}$} & \multirow{2}{*}{$\begin{array}{l}\text { Ages } \\
(y)\end{array}$} & \multicolumn{2}{|c|}{ No of patients having procedure } & \multicolumn{3}{|l|}{ No of deaths } & \multirow{2}{*}{$\begin{array}{l}\text { Longest } \\
\text { follow } \\
\text { up }(y)\end{array}$} \\
\hline & & & Total valve replacement & Plication & In hospital & Later & Total & \\
\hline $\mathrm{Ng}$ et al $1979^{10}$ & 10 & $5-31$ & $\begin{array}{l}10 \\
\text { Homograft } 9 \\
\text { Dura mater } 1\end{array}$ & 10 & 3 & 1 & 4 & 9 \\
\hline Melo et al 1979"1 & 2 & 15,21 & Starr-Edwards & & & & & 11 \\
\hline $\begin{array}{l}\text { Bove and Kirsch } \\
1979^{12}\end{array}$ & 5 & $11-57$ & $\begin{array}{l}5 \\
\text { Starr-Edwards } 3 \\
\text { Hancock } 2\end{array}$ & 1 & & & & 13 \\
\hline $\begin{array}{l}\text { Barbero-Marcial et al } \\
1^{1979}\end{array}$ & 20 & $4-31$ & $\begin{array}{l}20 \\
\text { Starr-Edwards } 10 \\
\text { Dura mater } 10\end{array}$ & 5 & 4 & 3 & 7 & 12 \\
\hline Shigenobu et al $1980^{\circ}$ & 11 & $15-65$ & $\begin{array}{l}\text { Kay-Shiley with } \\
\text { complete } \\
\text { muscle guard } 10 \text {, } \\
\text { without muscle } \\
\text { guard } 1\end{array}$ & 2 & 1 & & 1 & 13 \\
\hline Caralps et al $1981^{19}$ & 2 & 15,16 & 2 & & & & & 3 \\
\hline Westaby et al $1982^{13}$ & 24 & $3-55$ & $\begin{array}{l}\text { Bjork-Shiley } \\
16 \\
\text { Porcine xenograft } 13 \\
\text { Mechanical prosthesis } 3\end{array}$ & 2 & 4 & & 4 & 13 \\
\hline Present series & 10 & $13-51$ & $\begin{array}{l}\text { Hammersmith } 1 \\
\text { Large Beall } 4 \\
\text { Homograft } 1 \\
\text { Carpentier-Edwards } 3\end{array}$ & & & 1 & 1 & 16 \\
\hline
\end{tabular}

remains unsettled. The Beall prosthesis clotted in two of our patients, in one fatally. Similarly a Björk-Shiley valve thrombosed 24 months after its implantation despite anticoagulation. Because of these complications the type of prosthesis used in this series has altered. In the last three patients we have used a Carpentier-Edwards bioprosthesis and have had no complications related to these valves in six years. The biological valves have a minimal risk of thromboembolism and their pliable cusps function well and give satisfactory early and medium term results. ${ }^{1024} \mathrm{We}$ do, however, need further experience of their life expectancy and long term results.

The prosthetic valve was inserted above the coronary sinus and atrioventricular node, as described by Barnard and Schrire, ${ }^{4}$ in eight patients. Damage to the conduction system was thus avoided. A few episodes of atrial arrhythmia in the postoperative period were managed easily. Troublesome arrhythmias without evidence of heart block were observed in the patient in whom the bioprosthesis had been placed below the coronary sinus and she required repeated admission for their treatment. She is, however, well 12 years after surgery. Patients haemodynamically improved by excision of the deformed tricuspid valve and its replacement by a competent prosthesis tend to stand these arrhythmias reasonably well and show a decrease in the frequency and duration of their occurrence. Sealy and associates, ${ }^{25}$ however, treated patients with tachyarrhythmias surgically, and electrophysiological investigation with surgical ablation in view should be carried out in patients with arrhythmias.

In conclusion, satisfactory long term results which improve the quality of life can be achieved in Ebstein's anomaly by tricuspid valve replacement without plication of the atrialised right ventricle. Heart block can be avoided by placing the sutures above the coronary sinus. Death because of prosthetic failure can occur and regular follow up after operation is essential. By haemodynamic correction with competent tricuspid prostheses, patients tend to tolerate arrhythmias satisfactorily and the frequency of these appears to diminish.

\section{Addendum}

After this paper had been submitted an 11 year old boy with Ebstein's anomaly was operated on unsuccessfully. He came off bypass without difficulty but 20 minutes later he developed atrial and then ventricular arrhythmia. This was followed by a severe low output state and death in the theatre.

\section{References}

${ }^{1}$ Ebstein W. Über einen sehr seltenen Fall von Insuffizienz der Valvula tricuspidalis, bedingt durch eine augoborene hochgradige Missbildung derselben. Arch Anat Physiol Wissensch 1866;33:238.

${ }^{2}$ Genton E, Blount SG. The spectrum of Ebstein's anomaly. Am Heart J 1967;73:395-425. 
${ }^{3}$ Zuberbuhler JR, Allevork SP, Anderson RH. The spectrum of Ebstein's anomaly of the tricuspid valve. $J$ Thorac Cardiovasc Surg 1979;77:202-11.

4 Barnard CN, Schrire V. Surgical correction of Ebstein's malformation with prosthetic tricuspid valve. Surgery 1963;54:302-8.

${ }^{5}$ Lillehei CW, Kalke BR, Carlson RG. Evolution of corrective surgery for Ebstein's anomaly. Circulation 1967;35,suppl:111-8.

${ }^{6}$ Kitamura S, Johnson JL, Redington JV, Mendez A, Zubiate P, Kay JH. Surgery for Ebstein's anomaly. Ann Thorac Surg 1971;11:320-30.

${ }^{7}$ Barbero-Marcial M, Verginelli G, Awad M, Ferreia S, Ebaid M, Zerbini EJ. Surgical treatment of Ebstein's anomaly. J Thorac Cardiovasc Surg 1979;78:416-22.

${ }^{8}$ Danielson GK, Fuster V. Surgical repair of Ebstein's anomaly. Ann Surg 1982;196:499-504.

'Shigenobu M, Mendez MA, Zubiate P, Kay JH. Thirteen years' experience with the Kay-Shiley Disc Valve for tricuspid replacement in Ebstein's anomaly. Ann Thorac Surg 1980;29:423-7.

${ }^{10} \mathrm{Ng} \mathrm{R}$, Somerville J, Ross D. Ebstein's anomaly: late results of surgical correction. Eur $J$ Cardiol 1979;9:39-52.

${ }^{11}$ Melo J, Saylam A, Knight R, Starr A. Long-term results after surgical correction of Ebstein's anomaly. $J$ Thorac Cardiovasc Surg 1979;78:233-5.

12 Bove EL, Kirsch MM. Valve replacement for Ebstein's anomaly of the tricuspid valve. $J$ Thorac Cardiovasc Surg 1979;78:229-32.

${ }^{13}$ Westaby S, Karp RB, Kirklin JW, Waldo AL, Blackstone EH. Surgical treatment in Ebstein's malformation. Ann Thorac Surg 1982;34:388-95.

${ }^{14}$ Watson H. Natural history of Ebstein's anomaly of tricuspid valve in childhood and adolescence: an international co-operative study of 505 cases. $\mathrm{Br}$ Heart J 1974;36:417-27.
15 Oldenburg FA, Nichol AD. Ebstein's anomaly in the adult. Ann Intern Med 1960;52:710-7.

${ }^{16}$ Seward JB, Tajik AJ, Feist DJ, Smith HC. Ebstein's anomaly in an eighty five year old man. Mayo Clin Proc 1979;54:193-6.

${ }^{17}$ Scott LP, Dempsey JJ, Timmis HH, McClenathan JE. A surgical approach to Ebstein's disease. Circulation 1963;27:574.

${ }^{18}$ Marcelletti C, Duren DR, Schuilenburg RM, Becker AE. Fontans operation for Ebstein's anomaly. J Thorac Cardiovasc Surg 1980;79:63-6.

${ }^{19}$ Caralps JM, Aris A, Bonnin JO, Solanes H, Torner M. Ebstein's anomaly: surgical treatment with tricuspid replacement without right ventricular plication. Ann Thorac Surg 1981;31:277-80.

${ }^{20}$ Hardy KL, May IA, Webster CA, Kimball KG. Ebstein's anomaly: a functional concept and successful definitive repair. J Thorac Cardiovasc Surg 1964; 48:927-40.

${ }^{21}$ Hardy KL, Roe BB. Ebstein's anomaly, further experience with definitive repair. $J$ Thorac Cardiovasc Surg 1969;58:553.

${ }^{22}$ Schmidt-Habelmann P, Meisner H, Struck E, Seboning F. Results of valvuloplasty for Ebstein's anomaly. J Thorac Cardiovasc Surg 1981;29:155.

${ }^{23}$ Sealy WC. The cause of haemodynamic disturbances in Ebstein's anomaly based on observations at operation. Ann Thorac Surg 1979;27:536-46.

${ }^{24}$ Senoo Y, Ohishi K, N-'a S, Teramoto S, Sunada T. Total correction of Ebstein's anomaly by replacement with a biological aortic valve without plication of the atrialised ventricle. J Thorac Cardiovasc Surg 1976; 72:243-8.

${ }^{25}$ Sealy WC, Gallagher JJ, Prichett ELC, Wallace AG. Surgical treatment of tachyarrhythmias in patients with both an Ebstein anomaly and a Kent bundle. $J$ Thorac Cardiovasc Surg 1978;75:847-85. 